\title{
INSIDE WASHINGTON
}

\section{Christopher Wright \\ Assistant Director \\ ALA Washington Office}

In a more lavish era federal programs were launched with televised ceremonies featuring cabinet officers, cheering bystanders, and a blast of bombast. But in these days of official miserliness new government projects are being sent into the world by the back door without so much as a pat on the back from the office staff. Sometimes a launching is so hesitant and the equippage so meager hardly anyone notices the program at all. Few expect it to survive.

The latest higher education program is one of these unfortunates.

The academic librarian interested in massive federal support, innovative ideas, or broad concepts of government can stop reading now. This program has few friends, little money, and a tenuous lease on life. Even if it survives it might just produce more red tape, more squabbling among education bureaucrats, and more empire building at the state capital.

Or it could produce a new era of cooperation, broad-based funding, and federal support for many aspects of higher education, including libraries.

Announced in a letter to state governors earlier this spring, the program contains a scant \$1 million for the states to use in planning higher education through a state postsecondary education commission (known as the "1202 Commissions" from the section in the Higher Education Act Amendments of 1972-P.L. 92318).

Governors were supposed to notify the Office of Education by April 15 if they intended to establish a commission or revamp an existing one to meet the new requirements. To qualify for funds the commission must be "broadly and equitably representative of the general public and public and private nonprofit and proprietary institutions of postsecondary education in the state."

In many instances the "new" commission will probably be a direct successor to a Higher Education Facilities Commission which oversaw the massive expansion of state universities, community colleges, and other institutions beginning in 1963. The commission will have the job of setting up special committees and task forces (not necessarily composed of commission members) which will make surveys and studies "or otherwise contribute the best available ex- pertise" with the aim of coordinating higher education throughout the state.

Presumably these commissions will act as local boards of trustees, overseeing the diverse federal investments in higher education, including federal support for community services and continuing education (HEA Title I), equipment for undergraduate instruction (VI-A), construction of undergraduate academic facilities (VII-A), and aid to community colleges and occupational education (X).

Except there isn't any money.

The \$1 million allocation for establishing the commissions and beginning planning means each state will get the ridiculous sum of $\$ 18,180$ if they all apply. This is hardly a drop in the bucket for states whose existing commissions often already have budgets ten or twenty times that sum. And the Administration isn't asking Congress for anything in this category next year.

Worse, all the grandiose federal programs the new commissions are supposed to administer are also proposed for extinction in the Administration's budget proposals for fiscal year 1975. What earthly good is a threadbare planning agency grimly processing proposals for which the government isn't budgeting one dime?

The answer lies in the renewed power of Congress.

The Administration's grudging acceptance of programs such as the 1202 Commissions this year, and its persistent refusal to budget money for higher education next year, are cause for outcry, but not for despair. Congress has been appropriating money in spite of the White House, and the courts have made the Administration spend the money. If a program is successful and its supporters are vocal, more money will be forthcoming. This year there's barely $\$ 1$ million here, but next year ...?

These 1202 Commissions are designed to become a major policy-making arm of state governors. The wording of the law automatically makes the commission a semiofficial spokesman for the education community in planning the future of higher education. The commission's influence over federal and state funds could be total.

Next year there may be more money for planning. And there may be money for higher education programs too. And for library construction. And for resources. The 1202 Commission may be the group who decides whether you get federal funds for a new building, or a new computer network. 